\title{
Thomas F. Mayer (1951-2014) and the Roman Inquisition: A review essay.
}

\begin{abstract}
This review article appraises the recent trilogy of books on the Roman Inquisition written by the late Thomas F. Mayer. It explains the context in which Mayer came to write these works, the research questions which guided him and the nature of the outputs he delivered before his untimely death. Mayer's principal theme, of the importance of process in guiding inquisitors' actions and activities, is traced through his three volumes: the first a general reconstruction of how the Holy Office operated, the second an application of his insights to specific cases of importance throughout late sixteenth- and early seventeenth-century Italy, the third on the Galileo trial itself. Other scholars have received Mayer's work in a number of different ways, some favourable, others less so. Here, this essay summarizes the parameters of the debate which Mayer catalyzed, in particular between scholars of Galileo and of the Inquisition; it also explains the further questions that has raised. Finally, it assesses how, as colleagues, we might extend Mayer's inquires and evaluates the wider impact his work deserves to have in historical studies and, indeed, in contemporary academic discourse. Mayer's insistance on the need to understand the methods and processes of censorship seems especially timely given the general assault on free speech which we currently face on many university campuses. On that basis, his scholarship should continue to resonate with all of us, perhaps in some uncomfortable ways.
\end{abstract}

Keywords: Thomas F. Mayer, Inquisition, Galileo, Censorship, History of Science, Maurice Finocchiaro.

Thomas F. Mayer, The Roman Inquisition: A Papal Bureaucracy and its Laws in the Age of Galileo. Philadelphia: University of Pennsylvania Press, 2013, 385pp., f52, ISBN: 978-0-81224473-1.

Thomas F. Mayer, The Roman Inquisition on the Stage of Italy, c. 1590-1640. Philadelphia: University of Pennsylvania Press, 2014, 361pp., f52, ISBN:978-0-8122-4573-8.

Thomas F. Mayer, The Roman Inquisition: Trying Galileo. Philadelphia: University of Pennsylvania Press, 2015, 368pp.; Price: f58.50. ISBN: 978-0-8122-4655-1.

The Roman Inquisition looms large in any assessment of early modern Catholicism - as, indeed, it must also do in one of either early modern religious or legal history. As Thomas Mayer notes in these volumes, it was a political machine designed to enforce orthodoxy. Many of its decisions and activities are justifiably notorious. Unsurprisingly, a long and distinguished line of Italian historians - from Benedetto Croce and Delio Cantimori to Adriano Prosperi and Massimo Firpo - have seen it as a root of Italy's cultural and political malaise in the centuries before the Risorgimento. Simon Ditchfield has noted that these historians more often than not have seemed to take the challenge of accounting for the 'defeat' of the Italian people by their clergy as their point of departure. ${ }^{1}$ However, the

\footnotetext{
${ }^{1}$ Simon Ditchfield, '"In search of local knowledge". Rewriting early modern Italian religious history', Cristianesimo nella storia 19 (1998), 255-290 and 'In Sarpi's Shadow: Coping with Trent the Italian Way', Studi in memoria di Cesare Mozzarelli (2 vols, Milan: Vita e Pensiero, 2008), 1:585-606.
} 
opening of Archivio della Congregazione per la Dottrina della Fede in January 1998 has boosted study of the Inquisition itself, rather than just its effect on its victims. In recent years a number of important studies have followed, focusing on inquisitors themselves, their careers and their professional culture. Firpo and Prosperi have both contributed to this trend, but Christopher Black, Peter Godman, Andrea Vanni, Jane Wickersham, and others have also made important interventions. This is the context within which Thomas Mayer, who sadly passed away in 2014, wrote his formidable three-volume study of the Roman Inquisition: 'A Papal Bureaucracy and its Laws in the Age of Galileo', 'On the Stage of Italy, 1590-1640' and 'Trying Galileo'. Most scholars will previously have known Mayer for his work on the English cardinal and Archbishop of Canterbury Reginald Pole, but in this trilogy he styled himself self-consciously a legal historian and set himself the task of reconstsructing inquisition procedure. How did it develop? What went on in the minds of the men who invented? How did it differ from the operations of other earlier or geographically disparate inquisitions? Mayer seems always to have intended the climax of this work to be a radical re-assessment of the infamous Galileo trial in 1615-16 and 1632-33. What would shining a light on his persecutors and their methods reveal about this complex and troubling episode in the Church's seventeenth-century past?

Mayer intended the first of his books to present a detailed description of how the Holy Office worked day-to-day in the first half of the seventeenth century. Most reviewers now seem to agree that he achieved this, offering the most complete picture we have to date. ${ }^{2}$ Mayer divided his work into four main areas in which he examined, respectively, the activity of inquisitors before 1623, under Urban VIII (1623-44), the role of their professional support staff, and their use of Inquisition procedure (Inquisitio). For this, Mayer drew on an astonishing array of manuscript sources from the Archivio della Congregazione per la Dottrina della Fede, cross-referencing them with others from the Archivio Segreto, the Biblioteca Vaticana and across Italy. The depth of his scholarship in this book is quite extraordinary and he makes a strong case that that the Inquisition's composition, authority and style depended to a significant degree on the intentions and policies of individual popes. Mayer used his second volume to expand this argument through a series of specific episodes that show the Inquisition 'on the stage of Italy' (as the title indicates). He presents five, spread around three of Italy's most important states: two chapters on Naples assess tensions with the Spanish Monarchy and the case of Tommaso Campanella, two on Venice examine the aftermath of the Interdict (1606-07) and dissenters in Venice (Giordano Bruno,

\footnotetext{
2 Federico Barberiato, 'The Roman Inquisition: a papal bureaucracy and its laws in the age of Galileo, by Thomas F. Mayer', The Catholic Historical Review 100 (2014), 154-55. Thomas Izbicki, 'The Roman Inquisition: a papal bureaucracy and its laws in the age of Galileo, by Thomas F. Mayer', Sixteenth Century Journal 45 (2014), 268-69. Thomas Renna, 'The Roman Inquisition: a papal bureaucracy and its laws in the age of Galileo, by Thomas F. Mayer', Church History 83 (2014), 497-99. Jane Wickersham, 'The Roman Inquisition: a papal bureaucracy and its laws in the age of Galileo, by Thomas F. Mayer', European Review of History: Revue européenne d'histoire 22 (2015), 842-43. Peter Mazur, 'The Roman Inquisition: a papal bureaucracy and its laws in the age of Galileo, by Thomas F. Mayer', The English Historical Review 130 (2015), 189-90. There are also, of course, further reviews in other European languages.
} 
Cesare Cremonini and Marcantonio De Dominis), and two on Florence trace the protracted trials of the Alidosi lords of Castel del Rio, feudatories of the grand duke. As in the first volume, Mayer argues that popes used the Inquistion as a tool of centralization but here modifies that by showing how local state authorities and, indeed, papal nuncios could in fact influence inquisitorial activity. The regularity and seriousness of disagreement between Inquisitors and those who hosted them is a major and important theme within the book.

It is now three years since the first of Mayer's volumes came out and two since the second. For that reason, it does not make much sense for me to offer a review ab initio here. Rather, I hope to highlight some of the interesting debates which his work has simulated amongst others who have read and enjoyed it. Reviews of 'A Papal Bureaucracy' were not only generally positive, but they also mostly accepted Mayer's position that Urban VIII was able to dominate the Inquisition's agents and mechanism. However, Anthony Wright has already drawn attention to the fact that Mayer himself had already recanted from this view somewhat by the time he published 'On the State of Italy': 'this book does not bear out particularly well one of the major conclusions of The Roman Inquisition, Urban VIII's unprecedented dominance of the institution'. ${ }^{3}$ One reason for that, as Wright points out, is the cases that Mayer chose to cover: Venice and Naples, though hugely significant in terms of Italian history, have already long been accepted as outliers in terms of how the the Holy Office was able to operate (tensions between Inquisition and both states were far greater than the norm). Moreover, the well-known cases he studies, though useful as background for a project on Galileo, were hardly typical even in these states (a point which Jonathan Seitz has also recently made). ${ }^{4}$ There is also a question of chronology: how much did it matter that these cases were not contemporaneous but spread over a fifty-year period? Our default presumption, as it was Mayer's in the first volume, must be for the nature of Inquisitorial activity to have changed both qualitatively and quantitatively during that time. But might Urban VIII's greater success at the expense of the Spanish in Naples than Paul V's at the expense of the Venetian Republic have been the result of non-theological factors? In fact, Andrea Del Col, reviewing for the Catholic Historical Review, has seen Mayer's willingness to consider the activities of inquisitorial tribunals over a relatively long period of time as one of the book's best features. ${ }^{5}$ However, Del Col has been more critical of Mayer's presumptions that 'the center's control over the periphery was of fundamental importance and that centralization was a pervasive phenomenon'. Del Col, not unreasonably, doubts that this was the case and cites an as yet unpublished article by Giuliana Ancona and Dario Visintin, 'Centro e periferia. Correlazione fra lettere e processi del Sant'Ufficio in Friuli tra il 1557 e il 1653' in support. But, of course, there are quite a large number of items of secondary literature which Mayer does not seem to have had time to incorporate into his discussion before publishing this volume (for example Gigliola Fragnito and Maria Teresa

\footnotetext{
${ }^{3}$ A.D. Wright, 'The Roman inquisition on the stage of Italy, c. 1590-1640. By Thomas F. Mayer', The Journal of Ecclesiastical History 66 (2015), 200-02. Mayer, On the Stage of Italy, 223.

${ }^{4}$ Jonathan Seitz, 'The Roman inquisition on the stage of Italy, c. 1590-1640. By Thomas F. Mayer', The American Historical Review 120 (2015), 733-34.

${ }^{5}$ Andrea Del Col, 'The Roman inquisition on the stage of Italy, c. 1590-1640. By Thomas F. Mayer', trans. Anne Jacobson Schutte, The Catholic Historical Review 101 (2015), 659-61.
} 
Fattori's work on the pontificate of Clement VIII). My personal view is that this should not necessarily matter in and of itself - if Mayer's arguments stand up on their own merits. But one thing which comes across in both volumes is that Mayer never fully developed his model for thinking about how the papacy and the papal office worked or about the Italian Church's overall bureaucratic structures. Such a background might have modified his arguments about the motivations and goals of inquisitorial activity considerably.

Many of recent criticisms of Mayer's work are clearly grounded in some justification. But this is not the place to develop them further against a man who cannot defend himself. In reflecting on these two volumes, we surely need to consider both what they have achieved and what additional questions and avenues of inquiry they are likely to stimulate amongst future scholars. For historians of the Roman Inquisition specifically, they seem to highlight two things: first, the rich variety of archival material which remains untapped and second, the need to go beyond the Holy Office's first hundred years to explore its activities and significance in the second half of the seventeenth century and into the eighteenth. It still sometimes feels as if the Galileo affair was such a major event within the history of the Holy Office that what happened after pales in comparison. Mayer's broadening of how we understand that history in the Galilean period ought to cause us to revise our pre-Galilean emphasis. His work will also perforce impact that of papal historians and historians of the ecclesiastical bureaucracy generally: though he does not overturn any current paradigms, he makes an overwhelming case for the Inquisition's role as a tool for enforcing papal policy. But the question then is how effective was it? And at what point did inquisitors begin to loosen themselves from direct papal control? Mayer's emphasis on the contingency of individual popes' attitudes is important in this regard and offers a useful point of comparison with observations Firpo and others have made about similarly contrasting inquisitorial fortunes under Julius III, Paul IV, Pius IV and Pius V. Social historians will also be grateful for Mayer's work, especially in the first volume: no other account of procedure is so clear or precise and that will mean it proves invaluable to a host of future studies.

Mayer's third volume has been eagerly anticipated, especially by those of us who heard him talk about this subject in the final years of his life. For him, this manuscript rather than its two predecessors was where his originality was to be felt most keenly. Much ink has been spilled over the Galileo trial in the last four hundred years, but Mayer's book was to be the first for several generations to assess it directly as a legal event - that is to explain what happened in terms of the relevant canon law. He hoped to show how Galileo's trial, far from being the politically motivated witch-hunt of older polemic, actually conformed to normal inquisitorial procedure with a high degree of consistency. To prove his case, he tried to identify the irregularities in the procedure and explain them as the consequence of actions by individual officials. Inevitably, this approach required a considerable prosopographical outlay and, as in the first volume, he creates (in his own words) 'capsule biographies...designed to help navigate the complicated world of Roman bureaucracy and courts'. ${ }^{6}$ The book enjoys a slightly more delineated structure than either 'A Papal Bureaucracy' or 'On the Stage of Italy', perhaps because of its greater chronological

\footnotetext{
${ }^{6}$ Mayer, Trying Galileo, 2.
} 
emphasis. An Introduction and Conclusion serve as bookends to seven chapters: one on the background to the trial ('The Florentine Opposition'), three on the first phase of the trial ('late 1614' to 1616) and three on the second phase, which Mayer traces from 1630 to 1634. The text is particularly fragmented into sub-sections - even more so than in the other two volumes - which may have been a result of the speed of writing; but that actually helps for navigating through Mayer's prose. What Mayer has produced is in its own way a rather elegant description of the trial's progress. But is also advances a clear thesis: that there was no plot to 'get' Galileo, the Inquisitors who tried him were only following their own wellestablished rules and procedures and that Galileo's condemnation is readily explicable in its contemporary context, even if today it seems to us self-evidently unjust.

Mayer must have anticipated that his defence of the Inquisition would arouse the ire of Galileo scholars and perhaps also criticism from historians more generally. Inevitably, disagreement has already materialised: Maurice Finocchiaro has written a review which pulls no punches in expressing his contempt for Mayer's scholarship. ${ }^{7}$ Finocchiaro's critique of Mayer essentially has three points: factual inaccuracies, incorrect interpretation of certain key documents and methodological flaws in his legal-historical approach. Of the three, the inaccuracies, a category which for Finocchiaro includes misleading translations, is surely the least contentious. He usefully corrects some inconsistencies in Mayer's text about Galileo's interaction with Antonio Barberini and the Tuscan ambassador Francesco Niccolini and draws attention to some debatable interpretations of the Italian language, especially where Mayer tries to iron out the inconsistencies in inquisitorial censure of Galileo. The key documents here are an injunction written by Michaelangelo Seghizzi and a certificate written by Roberto Bellarmine: the former purported to order Galileo to decease from Copernican teaching, the latter of which gave him the green light to do so (they are dated respectively $26^{\text {th }}$ February and $26^{\text {th }}$ May 1616). Mayer, unlike some previous scholars, assumes them both to be genuine and sets about reconciling the apparent contradiction in their content - as well as that between Bellarmine's certificate and the subsequent decision to re-investigate Galileo in the 1630s. Finocchiaro objects that Mayer's reading of these texts is essentially arbitrary, conflating not only their material authenticity and historical accuracy but also their legal validity. Finally, Finocchiaro challenges Mayer's conception of law, which he describes as 'hyper-legalistic, hyper-formalistic, and self-defeatingly meticulous'. The problem is this: that Mayer's argument depends on assuming that in particular moments inquisitorial officials did not know what they were doing and thus acted illegally, but that this dependence in itself brings notions of legality into question. If officials did not know, or did not care, what the procedures were - and in the course of the three volumes Mayer provides strong prima facie evidence for this often to have been true - then why analyze the trial in legal terms at all? Of course, this is a more general problem affecting all attempts to operate exclusively within a framework of fixed rules or structures (and legal scholars are well aware of this). One way of overcoming that might perhaps be Mayer's prosophographical approach - that is, to reconstruct the individual personalities and intellectual formations of particular officials to show how and why their actions deviated

\footnotetext{
7 Professor Maurice A. Finocchiaro, review of The Roman Inquisition: Trying Galileo, (Reviews in History, review no. 1836), DOI: 10.14296/RiH/2014/1836, Date accessed: 7 January, 2016.
} 
from proscribed norms. But, as Finocchiaro notes, this would require a more considered and targeted approach than Mayer was able to achieve in this volume as it now stands. There is too much detail here included for its own sake and it distracts from the overall case he has tried to build.

Christopher Black, one of the original peer-reviewers for Mayer's manuscripts, has written a measured response to Finocchario's complaints (available beneath the original review). Black interprets Finocchario's position as, in essence, the product of a clash between Galilean and Inquisitorial scholarship - proponents of both, he implies, may perhaps be necessarily predisposed towards their subject of study. Certainly, in the case of Galileo this is readily apparent: there have been few accounts of his life that give full measure to what one suspects were the more difficult sides of his personality or are as willing to present him as an author of his own misfortunes as Mayer is here. Yet there is a fine line between explaining how Galileo's actions contributed to his difficulties and appearing to condone his trial on the basis of his actions. Diarmaid MacCulloch has already called Black out for an unfortunate phrase in his own verdict on the Inquisition: 'Galileo could have suffered worse'. ${ }^{8}$ Black's point was that the number of inquisitorial victims amongst Italian intellectuals was far fewer and the intensity of persecution they suffered far lower than legend would suggest. But it is indeed hard to advance that argument without sounding callous or to exude 'a whiff of that wonderful parody of fair-mindedness in ... historical judgments', as MacCulloch puts it. But how then should we write about the Inquisition? Do we have to condemn them every time? Both Mayer and Black in their respective works unwittingly draw attention the dangers of appearing to engage in moral equivocation. Even the late Owen Chadwick, investigating the wartime papacy of Pius XII had little time for the position that historians should set aside any moral component when tackling such controversial subjects: 'Moral judgment corrupts the historian and yet moral judgment is the essence of the man', as he put it in his address at the memorial service for Herbert Butterfield in $1979 .{ }^{9}$ Yet, clearly it also has to be possible to confront what we find objectionable - a category which surely includes the Inquisition - without having to issue a trigger warning or a caveat about it each time; equally, it is surely also preferable to be able to treat Galileo as something other than as a secular saint and to be free to investigate how inquisitors reacted to him on their terms rather than his. Mayer deserves some credit for showing us a viable way of doing this and his ability to rethink shibboleths is a virtue of this his final book.

So, in what further directions might other scholars now take Thomas Mayer's work? One which Mayer might have admired would be to draw on his legalistic approach in further study of other Inquisitions. Indeed, Katherine Aron-Beller has drawn attention to the value of applying his analysis in this way in her review of 'A Papal Bureaucracy' and Mayer himself hints at the need for such revisionism in his remarks about Francisco Bethencourt's

\footnotetext{
${ }^{8}$ Christopher Black, The Italian Inquisition (New Haven: Yale University Press, 2009), 207.

9 'Owen Chadwick: Obituary', The Times, 20th July 2015.
} 
comparative study of early modern Inquisitions in the introduction to that volume. ${ }^{10}$ In Mayer's view, this would likely rehabilitate other inquisitions - not in the sense that we accepted the morality of their actions, but in the more limited one that we understood how they operated within their own structured regulatory frameworks. A study which fulfilled Mayer's vision would perhaps not only go a long way towards diluting what remains of the Black Legend's continuing influence, but - in my view, far more importantly - might even help us better understand why some in other respects good men did such profoundly bad things. Of course, that should be a question of paramount importance for anyone who studies sixteenth-century religious history, which is replete with turmoil, violence and unspeakable atrocity. There must be some way of addressing that and Thomas Mayer has, at least partially, outlined a path. On the specific subject of Galileo, I suspect that some of the points Mayer raises will continue to resonate with academic discourse. We live in an age when, unfortunately, censorship of ideas is on the rise. Not for nothing has the bioethicist Alice Dreger entitled her study of politically motivated attacks on science Galileo's Middle Finger. ${ }^{11}$ Dreger's point is that individuals on both the Left and the Right are quite prepared to use norms, regulations and procedures to smear those with whom they disagree and stifle legitimate debate. Because Mayer shows how that happened in the original Galileo trial, his work ought to be of interest to anyone concerned with what is happening in universities today. It may be that much of what he says has been said before by greater Galilean scholars, but even if so there is currently some troubling news for all of us in the Academy: it has not filtered through to all of our colleagues or students yet.

${ }^{10}$ Katherine Aron-Beller, 'The Roman Inquisition: a papal bureaucracy and its laws in the age of Galileo, by Thomas F. Mayer', The American Historical Review 119 (2014), 627-28. Mayer, A Papal Bureaucracy, 5.

${ }^{11}$ Alice Dreger, Galileo's Middle Finger: Heretics, Activists and the Search for Justice in Science (London: Penguin, 2015). 